nia's decision to legalize it for that purpose in 1996.

In 1999, the Institute of Medicine reported "a potential therapeutic value for cannabinoid drugs," particularly for pain relief, control of nausea and appetite stimulation (http://books.nap .edu/openbook.php?record_id $=6376 \&$ page $=\mathrm{R} 1)$. That study said the benefits are modest, often surpassed by other medications and associated with "a powerful drug with a variety of effects." Still, it found the adverse effects to be within the range tolerated for other medications for certain patients.

Now, the federal government's nuanced shift on medicinal marijuana enforcement comes as little surprise, given Obama's stance in the 2008 presidential campaign.

"I think the basic concept of using medical marijuana for the same purposes and with the same controls as other drugs prescribed by doctors - I think that's entirely appropriate," he said then.

He further vowed: "I would not have the Justice Department prosecuting and raiding medical marijuana users.'

Obama, 49, is a child of the 1960s but not of the counterculture: He was only six when Woodstock happened. Yet his generation had plenty of exposure to drugs, and he has acknowledged using marijuana and cocaine in his youth to "push questions of who I was out of my mind." His predecessor in office, George W. Bush, routinely cracked down on medical marijuana purveyors, regardless of state law, and maintained restrictions on veterans that Obama is only now relaxing.

Veterans Affairs policy had stated that patients treated at VA hospitals and clinics could be denied pain medication if they were found in drug testing to have used an illicit substance.

Now, says Dr. Robert A. Petzel, the
VA's undersecretary for health, "if a veteran obtains and uses medical marijuana in a manner consistent with state law, testing positive for marijuana would not preclude the veteran from receiving opioids for pain management" in a VA facility.

Washington's decision to let state laws take precedence eases matters for patients but leaves patchwork rules in place.

Only New Mexico, for example, explicitly allows people with posttraumatic stress syndrome - a common condition of veterans returning from the Iraq and Afghanistan wars - to use medical marijuana. California doctors can recommend medical marijuana for any illness for which pot provides relief. Other states are more restrictive. - Cal Woodward, Washington, DC

DOI:10.1503/cmaj.109-3334

\title{
Patient charters all buzz and no bite, advocates say
}

Previously published at www.cmaj.ca

$\mathrm{P}$ atient groups are skeptical that a national charter of patient rights would reap real-world changes in Canada's health care system.

The Canadian Medical Association's recent proposal that a national patient charter be established in Canada follows on the heels of two decades of efforts to legislate patient rights at the provincial level, a hit-and-miss experience that's left patient groups questioning the necessity of such a document.

It's commonly held that patient charters provide people with a bit of ammunition in dealing with indifferent or stubborn health care bureaucracies, helping them to obtain information about their conditions from health care providers or about medical mishaps.

But the creation of a national charter listed low among health consumer priorities at the Canadian Patient Summit in March, says Karen Philp, chair of the summit and CEO of the Canadian Wound Care Association. "Their attitude was, 'Well that's nice, but let's not spend too much energy on it, and if we could forego the charter altogether and just implement the content, then that would be great.' It just wasn't on the radar."

The summit brought together some 200 people representing more than 30 patient organizations across the country. According to Philp, many participants said a charter should come after, not before Canada tackles more nutsand-bolts changes to system. Drafting a charter any sooner would only "bog down" necessary reform with "a lot of lip service."

Summit participants identified a number of more pressing health care reforms, says Philp, such as reducing wait times, implementing a national catastrophic drug plan and improving access to health care providers and services.

If systemic change doesn't precede the creation of a national charter, implementation will likely be an uphill battle, says Chris Summerville, CEO of the Schizophrenia Society of Canada. "Until you deal with the issues of supply and demand, it's going to be very difficult to honour the spirit of a charter."
The inherent difficulty of implementing a charter from the top down is among the reasons previous attempts to legislate patient rights at the provincial

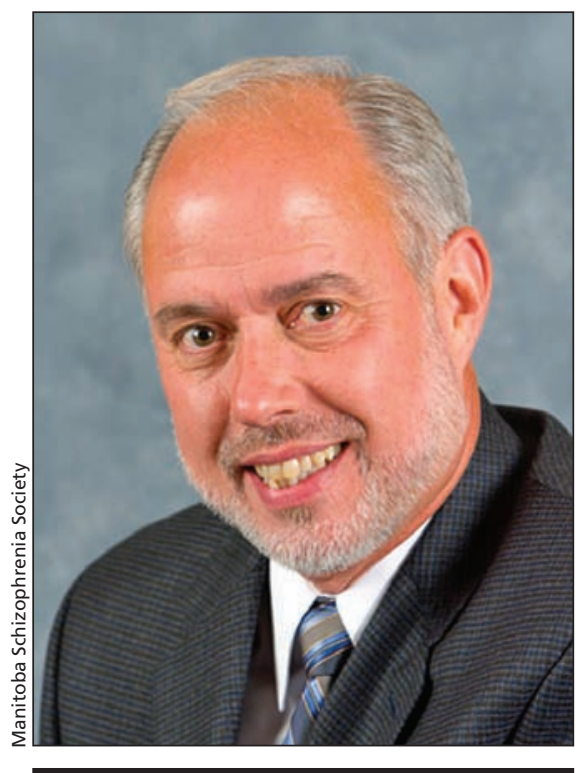

"Until you deal with the issues of supply and demand, it's going to be very difficult to honour the spirit of a charter," says Chris Summerville, CEO of the Schizophrenia Society of Canada. 
level have been largely unsuccessful, says Kathy Kovacs Burns, cochair of the Best Medicines Coalition, a national alliance of advocacy groups that represents people living with chronic diseases. "Charters are valuebased documents, so they really pose a challenge for governments to legislate and monitor."

Fears that enshrining patient rights in law would mean imposing "unreasonable demands" on physicians and opening up provincial governments to lawsuits have also posed an obstacle, says Philp.

Various hospitals, clinics, medical associations and societies across Canada have introduced nonbinding patient charters in recent years, but they've had "a limited effect on the well-being of patients and are primarily used for educational purposes," she says.

"I don't honestly believe anything has changed as a result of that exercise, except maybe the patients' sense of solidarity and vision moving forward," adds Louise Binder, chair of the Canadian Treatment Action Council, a nongovernmental organization run by and for people living with HIV/AIDS. "I've yet to be convinced that a charter of anything gets you very far, unless it's enshrined in law and can be enforced in some meaningful way."

While the Canadian Medical Association doesn't outline an accountability framework for the proposed national charter in the recent health reform blueprint Health Care Transformation in Canada: Change that Works, Care that Lasts, the association does state that "the Charter needs to be accepted by governments, providers, and patients to have an impact" (www.cma.ca/multimedia/CMA /Content_Images/Inside_cma/Advocacy /HCT/HCT-2010report_en.pdf).

Delegates to a special session on metrics for health care concluded that a patient-centred charter for quality must have adequate accountability measures if it is to result in improvements in Canada's health care system (www.cmaj .ca/cgi/doi/10.1503/cmaj.109-3192).

If government invests in a widespread education campaign, reporting tools for patient complaints and significant consultation with both patients and physicians, the goals of the charter may even be achievable without regulation,

\section{Preonar 13 Pneumococcal 13 -valent Conjugate Voccine (Diphtheria CRM Prip Protin)}

\section{Providing the broadest coverage of S. pneumoniae serotypes indicated in a pneumococcal conjugate vaccine $e^{-1,2,3}$}
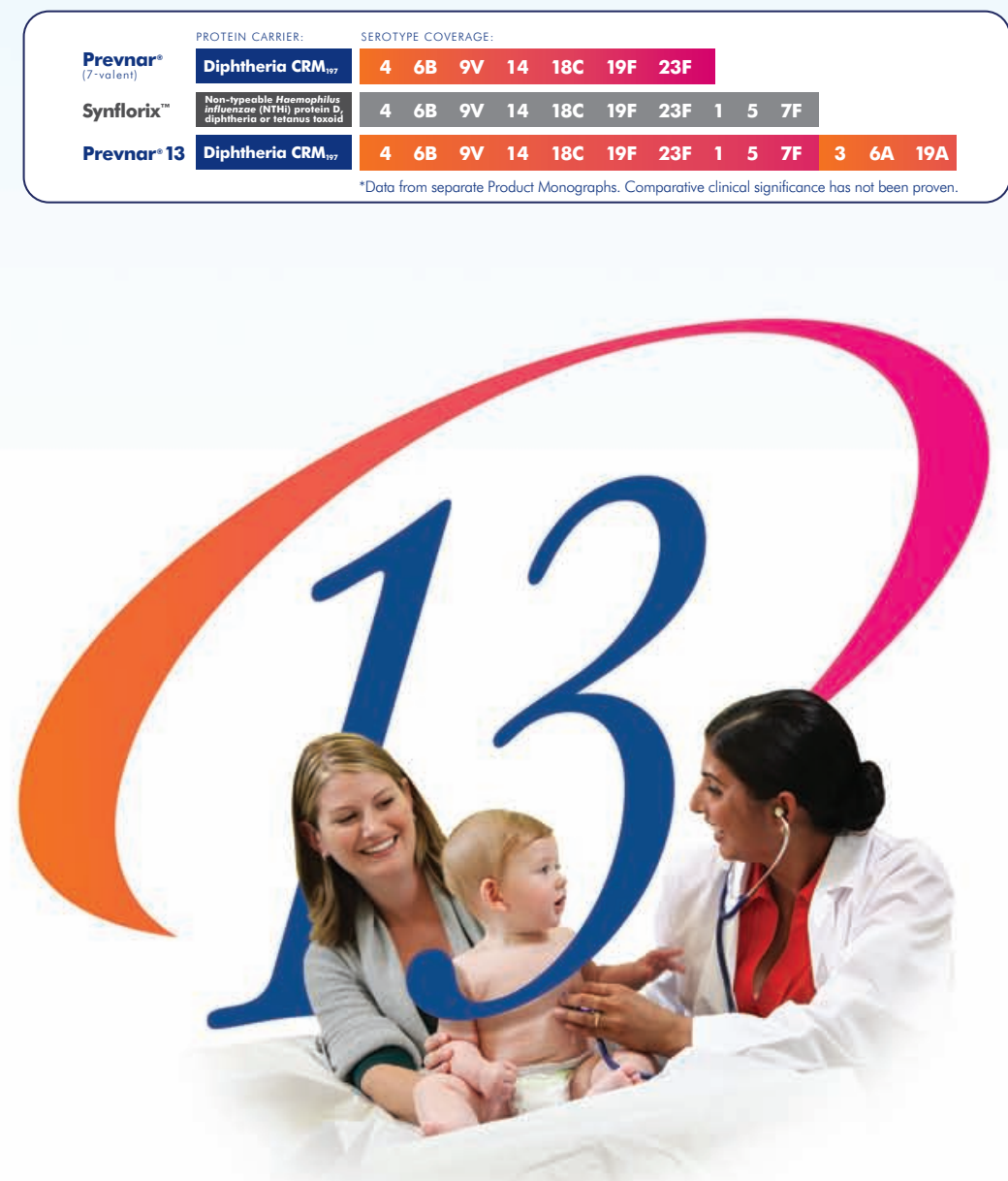

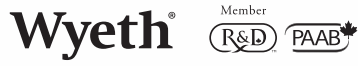

(i) 2010 Wyeth Canada
Montréal, Canada H4R 1 J6

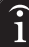


says Kovacs Burns. "There are lots of international charters put out by the World Health Organization and other groups that are respected without being legislated, so it's possible. But so long as we're operating in silos, there's no ownership in these policies."

It's all too easy for nonbinding policy to become diluted in the murky waters of federal and provincial responsibility, says Binder. "I don't think you'll ever see something like that implemented on a national level because the federal government will say it's the jurisdiction of the provinces, and I doubt the provinces will want to take on the cost of enforcing this thing."

Past recommendations that the federal government enact a national patient charter have "died a natural death" for that very reason, says Philp, citing failed federal private members' bills tabled in the early-2000s.

But more important than the charter itself is the opportunity it will provide for patients to join the discussion on health care transformation, she says. "It's about time we had a conversation across the country about the future of health care, and at least this is sparking discussion about what's best for patients, first and foremost."

To date, conversations surrounding patient charters have been fairly onesided, says Frances Jewell, executive director of the Mental Health Rights Coalition of Hamilton, an Ontariobased advocacy group. "Patient-centred care is a sexy buzzword right now, and people are eager to jump on board. But who's determining what the patients' needs are? I'm regularly contacted last minute when a group wants to push some charter or patient-centred policy through, and out of the blue they want me to rubber stamp this and throw together a consumer panel on that, because they're on a deadline. I don't appreciate well-meaning organizations speaking on my behalf."

Canada's checkerboard experience with patient charters means it's anyone's guess if a national charter will be more buzz or bite, she says. "It's been easy to direct services for people and say we're doing patient-centred care. That's no longer acceptable." - Lauren Vogel, CMAJ

DOI:10.1503/cmaj.109-3340

Second in a three-part series on patient charters

Part I: Patients charters: the provincial experience (www.cmaj.ca/cgi/doi /10.1503/cmaj.109-3339)

Part III: Patient charters: the international experience (www.cmaj.ca/cgi/doi /10.1503/cmaj.109-3342)

\section{Nation's physicians urge re-opening of Canada Health Act}

Previously published at www.cmaj.ca

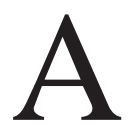
n overhaul of the Canada Health Act, detailed financial information about the long-term costs of health care and re-examination of the role and responsibilities of physicians in managing health care are among elements identified as integral to transformation of the health care system during the 143rd annual general meeting of the Canadian Medical Association.

The list included a call for the inclusion of "sustainability" as a new core and protected principle of medicare, as well as a "re-interpretation" of the Canada Health Act's five principles: universality, accessibility, portability, comprehensiveness and public administration.

The call for concrete information about the costs of health care came from Auditor General of Canada Sheila Fraser, who contended Canada should not make decisions about health care reform without long-term cost projections on the order of 25 or more years.

The role of doctors in the system, meanwhile, prompted the gathering's most heated debate, with some physi- cians decrying the marginalization of physicians in the management of the system and others arguing that doctors should eschew greater involvement in medicare on the grounds that the system's collapse is inevitable. CMA was charged with establishing a working group to investigate the issue.

Delegates adopted a pair of motions aimed at overhauling the Canada Health Act (CHA). One supported recognition of a sixth principle, "sustainability," that would define "standards of health human resources, infrastructure, clinical

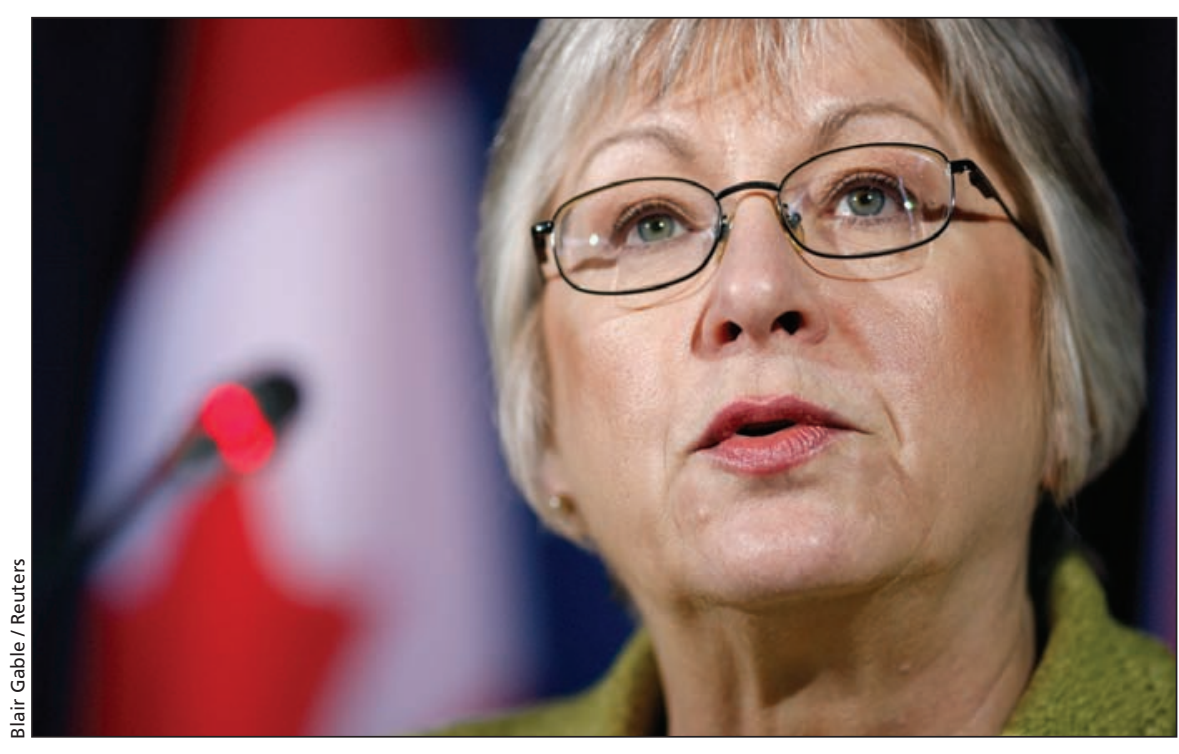

Canada should not make decisions about health care reform without long-term cost projections on the order of 25 or more years, says Auditor General of Canada Sheila Fraser. 